\title{
Cosmopolitan: A Tale of Identity from Ottoman Alexandria
}

\section{Citation}

Jasanoff, Maya. 2005. Cosmopolitan: A tale of identity from Ottoman Alexandria. Common Knowledge 11(3): 393-409.

\section{Published Version}

doi:10.1215/0961754X-11-3-393

\section{Permanent link}

http://nrs.harvard.edu/urn-3:HUL.InstRepos:3892592

\section{Terms of Use}

This article was downloaded from Harvard University's DASH repository, and is made available under the terms and conditions applicable to Other Posted Material, as set forth at http:// nrs.harvard.edu/urn-3:HUL.InstRepos:dash.current.terms-of-use\#LAA

\section{Share Your Story}

The Harvard community has made this article openly available.

Please share how this access benefits you. Submit a story.

\section{Accessibility}




\title{
COSMOPOLITAN
}

\section{A Tale of Identity from Ottoman Alexandria}

\author{
Maya Jasanoff
}

July 20, I767, Alexandria, Egypt: a muggy season, when haze mutes the sun and the sea sits flat. Around noon, Etienne Roboly walks to the old port, northwest along the great curve of the harbor. He is the chief dragoman, or interpreter, for the French consulate, and has lived in Egypt for some thirty years. He knows the place about as well as anyone. As dragoman, Roboly not only interprets between French, Turkish, and Arabic (the word dragoman is derived from the Arabic verb "to translate") but often conducts negotiations with Ottoman and Egyptian authorities himself. Well-versed in local protocols, and deeply acquainted with the customs agents, Roboly also dabbles in private commercial ventures of his own: trading, and sometimes smuggling, through Alexandria with the help of collaborators in other Mediterranean entrepôts.

This has been a difficult summer in Alexandria. Fever, which visits the city with nearly annual regularity, is rife. Demands and extortionate taxes (known as "avanias") from the port officials are becoming more frequent and more appalling. Westerners are moving cautiously. All this the dragoman knows. But in his long Turkish-style robes, the usual clothing for men of his profession, Roboly attracts no notice. He, at least, should be safe. Then suddenly there is a hand on his shoulder. It is the hand of a well-dressed Turk, who knows Roboly's name, his business, and some of his acquaintances in Constantinople. Is the man a friend of a friend? Roboly walks on further with him. Within minutes, catastrophe is upon 
him. The Turk, it turns out, is an officer of the sultan, armed with an order issued by the grand vizier to arrest the dragoman. Roboly is beaten, abused, and dragged on board the Ottoman ship Reala, where he is imprisoned in chains.

I read about this incident in a letter from the French consul in Alexandria to his superiors in Versailles, bound up in a volume of diplomatic correspondence in the Archives Nationales in Paris. ${ }^{1}$ I was researching cultural exchange on imperial frontiers; I had encountered Roboly earlier in my readings, and my curiosity had been piqued by this character who seemed (not least because of his occupation) the very type of a "marginal" European, seeking out overseas opportunities. Before I could read on, the archive closed for the day, and I was on tenterhooks wondering about the rest of the story. Why was the dragoman arrested? What happened to him next? I would soon discover that his life story held greater relevance to questions of nation, empire, and identity than I had anticipated.

I had been drawn to these volumes in the first place because I was curious about the origins of European imperial desire in Ottoman Egypt. Inspired in part by Edward Said, who famously identified the French invasion of Egypt (I798-I80I) as the launchpad of modern Orientalism, I wanted to turn the page back to the period before the French invasion. Looking to these decades, when European ambitions were only beginning to take shape, and when Europeans constituted a small and relatively weak minority in Ottoman domains, helped to frame questions of culture and power in different terms. In the dispatches and memoranda of French diplomats-documents rarely consulted by cultural historians-I found not so much the foreshadowings of Orientalist discourse as repeated evidence of the cross-cultural relations that formed part of daily life for French nationals living in an Eastern, Muslim, imperial domain. The consular records were a treasure trove of incidents and encounters: adultery, madness, murder, apostasy, antiquities, the drunken escapades of French sailors on shore, or the regular avanias levied against French commerce by Ottoman authorities. The lines between empowered and powerless, even East and West, did not always seem clearly drawn; nor did individuals' allegiances necessarily fit neatly within the borders between cultures or nations. Roboly's story in particular, as it unfolded in the dispatches, cast the ambiguities of national versus imperial identity into relief. It underscored the point that empires-while they develop hierarchies and rhetorics of difference-also contain considerable potential for crossing and cosmopolitan mixing.

I. Etienne Fort to the ministry of foreign affairs in Versailles, July 23, 1767 , Archives Nationales de France, Paris (hereafter cited as $\mathrm{AN}$ ): $\mathrm{AE} \mathrm{B/I/Io9.}$ 
Alexandria, Roboly's home, had been a hub of cosmopolitanism since ancient times. The city was perhaps history's first melting pot, and was inhabited in antiquity by Egyptians, Greeks, Jews, Romans, and such a wealth of Christian sects-Orthodox, Arian, Monophysite, Gnostic — that "Christians," a baffled Emperor Hadrian wrongly concluded, must be "those who worship Serapis," or Jupiter. ${ }^{2}$ You can still descend directly into the cosmopolitan world of the ancients, in the labyrinth of tombs that winds beneath the streets. In the catacombs of Kom ash-Shuqaffa, you can see Egyptian figures, standing with fists clenched, one foot before the other-but their heads are Roman portrait busts. There are bodies of Roman legionaries, wearing sandals, armored skirts, and breastplates-but they are topped with the animal heads of the Egyptian gods: jackal, ibis, and hawk. Crowned, knotted serpents, and Apis bulls, figments of the weird pantheon of Ptolemaic Egypt, join Medusa and Horus on the walls. This is a place of fusions and mixtures, survivals and innovations. ${ }^{3}$ And well into the twentieth century, when approximately a third of its residents were non-Arab or non-Egyptian, Alexandria remained a byword for diversity. The city's greatest poet, C. P. Cavafy, was Greek; the city's best-known prose memorialist, Lawrence Durrell, managed to write four novels about Alexandria without including a single major Muslim character. ${ }^{4}$ The Italian poet Giuseppe Ungaretti was born in Alexandria in $\mathrm{s} 888$, to a father who had emigrated from Tuscany to work on the Suez Canal. The historian Eric Hobsbawm was also born there, to British and Austrian Jewish parents in I9I7. The same year, another Briton in Alexandria, the novelist E. M. Forster (working for the International Red Cross), enjoyed a freedom he had not experienced in Britain by beginning a love affair with a tram conductor named Mohammed el Adl. ${ }^{5}$

Alexandria's status as a haven for foreigners, entrepreneurs, and outcasts may come as no surprise considering the crosscurrents of trade, culture, and migration that have always linked the shores of the Mediterranean. But the city's age-old cosmopolitanism owes as much to its history as it does to geographical setting. For, during most of its past, Alexandria was an imperial city. Founded by the Greeks, conquered by the Romans, ruled by the Arabs and the Ottomans, occupied briefly by the French and later by the British, Alexandria has flourished (and not) within empires extending over such far-flung regions as Algeria, Bulgaria, Australia, and Jamaica. Modern Alexandria boasted an international aura,

2. Anthony Sattin, The Pharaob's Shadow: Travels in Ancient and Modern Egypt (London: Indigo, 2000), 40.

3. Jean-Yves Empereur, A Short Guide to the Catacombs of Kom el Shoqafa, Alexandria, trans. Colin Clement (Alexandria, Egypt: Sarapis, 1995). Cf. William Dalrymple, From the Holy Mountain: A Journey in the Shadow of Byzantium (London: Flamingo, 1998), 382-84.
4. On cosmopolitanism in modern Alexandria, see Robert Ilbert and Ilios Yannakakis, eds., with Jacques Hassoun, Alexandria, I860-1960: The Brief Life of a Cosmopolitan Community, trans. Colin Clement (Alexandria, Egypt: Harpocrates, I997), I8-88.

5. Michael Haag, Alexandria: City of Memory (New Haven, CT: Yale University Press, 2004), 28-53. 
with Europeanizing architecture and a grid street plan, laid out in the nineteenth century by Egypt's ruler Muhammad Ali Pasha (himself an ambitious imperialist) and his successors; with an economy built on trade in wider imperial networks; and most conspicuously with a population marked by Greek, Italian, Syro-Lebanese, Jewish, and British communities, among others. As long as Alexandria was a city of empires, it was a city of many cultures. Today so much attention is paid to the way that empires divide people against each other that it is easy to forget how empires have also brought populations together, forcibly at times, yet often with enduring effects. The cosmopolitan possibilities of empire, as opposed to narrower definitions of national belonging, would shape the life of Etienne Roboly for good and for ill-just as they would shape the city in which he lived.

Alexandria was not bustling in Roboly's time. By the mid-eighteenth century, a combination of frequent plague epidemics and bad water supply had reduced Alexandria's population to five thousand or so residents, while nearby Rashid (Rosetta) was a flourishing town three times the size. Alexandria remained significant, however, as the only port in Egypt capable of harboring large ships and as the busiest port in the southeastern Mediterranean. Maritime trade was its lifeblood, exporting cotton, coffee, rice, and untanned leather, while importing textiles, paper, iron, silver, and gold. Power rested locally in the hands of Janissary governors and Jewish customs agents. (The latter would lose their offices, violently, to Syrian Christians in I768.) Muslim merchants, particularly from the Maghreb, dominated Alexandria's commerce, but there were merchant houses from every European Mediterranean region with the apparent exception of Spain; and Austria, Holland, Sweden, and (sporadically) Britain were all represented there by chargés d'affaires. ${ }^{6}$

In addition to running a permanent consular establishment in Alexandria, France maintained a resident population of civilians with it. They lived in an oquelle (English okel, derived from the Egyptian Arabic word wikala), a multistory compound with a central courtyard, which was divided into fifteen separate dwelling units, shops, offices, and a chapel. ${ }^{7}$ The community called itself la nation, and each year, the consul sent his superiors at Versailles a list of its members, almost all of whom were from Provence: eight or ten businessmen and clerks, a few domestic servants and carpenters, an innkeeper, and, for a time, a

6. Michael J. Reimer, Colonial Bridgehead: Government and Society in Alexandria, $1807-1882$ (Boulder, CO: Westview, 1997), 25-4I; Michael Winter, Egyptian Society Under Ottoman Rule, I5I7-I798 (London: Routledge, I992), 26. On the customs revenue of Alexandria, which was jointly collected with Rashid's, see Stanford J. Shaw, The Financial and Administrative Organization and Development of Ottoman Egypt, 15I7-I798 (Princeton, NJ: Princeton University Press, I962), I09-IO.
7. Vallière to ministry, December 16, I769, AN: AE B/ I/Io8. The Alexandria okel was in present-day Anfushi, on the eastern harbor (the only one open to European ships), and near the customs house. A wikala is a caravanserai or rest house; many can still be seen in Islamic Cairo. 
wigmaker from Grenoble. ${ }^{8}$ In outline, the French in Alexandria seemed to be a modest little nation of secluded, busy, God-fearing folk. ${ }^{9}$ But the tidiness of this picture is misleading. Contemporary lists of French subjects and protégés drawn up for other Near Eastern ports give a much more complete image of the kinds of communities these often were. ${ }^{10}$ The Alexandria consuls only listed the males of la nation, but their wives often would have been Greek or Italian, and quite possibly Ottoman subjects. Consular lists for Alexandria also (unlike those for Smyrna, for instance) excluded non-French residents of the okel, as well as people under French protection living outside it. The likely reality is that most of these French men were married to non-French women, sharing their compound with non-French neighbors - and, of course, conducting all their daily business with non-French merchants and officials, in languages, more likely than not, other than French. The streamlined "French" community that Alexandria consuls described may suggest a certain anxiety about how "national" it really was.

Never were the boundaries of la nation more obviously threatened than when a Frenchman decided to "turn Turk" (se faire turc) or convert to Islam. Consuls did not say, and perhaps did not know, how often Frenchmen slipped through their net, settling down with Muslim women, or taking jobs on Turkish or Maghribi ships. But the cases in which the consuls intervened were frequent, striking, and poignant. There was the young monk from Languedoc who turned up in Egypt with a declaration of Islamic faith in his pocket. "Happily," the consul "was able to arrest him at the very moment at which he apostatized," and he was sent back to his parents by the next available ship. ${ }^{11}$ More shocking was the case of Rashid's French priest, who decided to convert after suffering years of ill treatment from his father superior. The priest took refuge with the aga of the Janissaries, where the consular officials were "frozen with surprise" to see him, "still clothed in the habit of his Order, and with the cord of St. Francis, but having on his head a white turban of an ordinary Janissary."12 There was Honoré Olivier, the leather buyer, who "went mad in consequence of a love affair" and insisted on turning Turk. "Since he would not stop crying out in Arabic that he wanted to apostatize," he too was saved from himself and packed off to Livorno on a Dutch ship. ${ }^{13}$

8. See, e.g., "Liste des françois qui Resident à Alexandrie, et qui s'y sont etablis avant le premier Janvier I758: Dans laquelle sont compris ceux qui sont venus s'y etablir, et qui ont discontinué de resider pendant le cours de la dite année," and similar lists for I762, I 766 , and I771, AN: AE B/III/290, ff. 23, I30, I60, 197. There had been a French baker in Alexandria (as in Cairo) until the early 1750 s, but he was forced out of business when French sea captains started patronizing cheaper Egyptian bakers instead. (Sulause to ministry, February I, I753, AN: AE B/I/IO7.)
9. For an overview of French life in Egypt at this time, see Raoul Clément, Les Français d'Égypte aux XVIIe et XVIIIe siècles (Cairo: Institut Français d'Archéologie Orientale, i960), I49-69.

Io. See lists in AN: AE B/III/29o. The records for Aleppo are especially thorough and revealing.

I I. D'Evant to ministry, July 25, I756, AN: AE B/I/ıо8.

I2. Chaillan to ministry, August I8, I769, AN: AE B/ I/970.

I3. Vallière to ministry, December 15, I760, AN: AE B/ I/IO8. 
And then, there was Etienne Sauvaire, womanizer, gambler, and pimp, who was on the verge of converting to Islam with his grasping Greek mistress, when the consul clapped him into chains: "I spared his family and la nation the discomfort of seeing him turn Turk."14

These and other less extreme crossings were part of daily life for the French community in Alexandria-and regulating them was part of Etienne Roboly's job as interpreter. Yet this invaluable servant to the interests and security of the French nation was himself, of course, a professional go-between, living on cultural borders. Many of the dragomans used in the various courts of the Ottoman empire were European renegades and converts; by the eighteenth century, most came from the Greek community in Constantinople's Phanar quarter. European embassies in the Ottoman empire generally recruited their dragomans from various Eastern Christian communities. ${ }^{15}$ But France, unique among European nations, trained its own dragomans beginning in I669. In Roboly's day, many French dragomans began their careers as young boys, when they were sent off to Constantinople or Smyrna to learn Turkish and Arabic under the watchful eyes of Capuchin friars. Others were born in the Near East, often into mixed French-Ottoman families, and also often into veritable dynasties of interpreters. The Fornetti family, for instance, whose scions could be found manning French Levantine consulates well into the nineteenth century, had been producing dragomans since about I600. ${ }^{16}$ The Robolys seem to have been something of an interpreting clan too, furnishing dragomans in Smyrna, Salonika, and Egypt. ${ }^{17}$

Raised partly in foreign lands and trained to speak (among other languages) Turkish, French, and Arabic with almost equal ease, a dragoman was the quintessential cosmopolitan - an insider and outsider rolled into one. As such, he was both an asset and a liability to his employers. On the one hand, dragomans had a native understanding of the local customs and rituals at the heart of diplomacy. More than the consul's tongue and ears, a dragoman served as his eyes and hands too-especially, as was often the case, when the dragoman had lived in the region much longer than the consul himself. It was not unusual for France's dragomans, for instance, to pay official visits and conduct negotiations without the consul even present. On the other hand, these were men of mixed, possibly suspect, loyalties. The French king was their master, and they lived in compounds with fel-

I4. Vallière to ministry, October 27, I758, and January Iо, I759, AN: AE B/I/IO8.

I5. Bernard Lewis, The Muslim Discovery of Europe (New York: Norton, 1982), 78-79. A fascinating book remains to be written on dragomans; but see the catalog for an exhibition organized by Jean-Michel Casa, François Neuville, Emile Mantica, and Stéphane Yerasimos, Enfants de langue et Drogmans (Istanbul: Yapı Kredi Yayınlar1, 1995) for some useful remarks.
I6. Enfants de langue et Drogmans, I7-50; "Mémoire envoyé par M. le Cte. De St. Priest Ambassadeur à la Porte sur les Officiers du Roy en Levant," AN: AE B/III/24I.

I7. Names drawn from index entries in $\mathrm{AN}$ series $\mathrm{AE} \mathrm{B/}$ III. 
low "French" subjects and protégés. Yet their strongest ties were not to Francewhere many had hardly been-but to their homes in the Ottoman empire, where they were rooted by family and job, pragmatism and preference. Until ı 806, for instance, French dragomans were given the choice between wearing "Oriental" dress and Western uniforms; nearly all opted for turbans and robes, in place of hats and tight trousers. ${ }^{18}$ In short, these were men for whom, as one of Louis XVI's ambassadors in Constantinople put it, France "is a fatherland in name only, and to which they have no desire to return."19

Like many dragomans of his time, Roboly seems to have maintained at best a distant connection to France. By his own account, he had been in Egypt since I 735 (we must take his word for it, because too many Robolys appear in the French records to allow one to track his early career precisely), which meant that when a new consul, Etienne Fort, came to take over the Alexandria office at the end of I762, he found in Roboly a chief interpreter with nearly three decades' service in Egypt. ${ }^{20} \mathrm{He}$ also found, as his reports reveal, a dragoman deeply enmeshed in local business and politics - and a man who might be more capable of running the consulate than he was, which both of them knew.

The new consul relied heavily on his veteran dragoman as an emissary, informant, and adviser. There were Turkish officials to be wooed, French sailors to be bailed out of trouble, and European commercial rivals to be outdone. Most important, there were the unpredictable customs officers of the port, whose fluctuating demands regularly had to be confronted and appeased. Fort entered the consulate at a particularly difficult time for foreign trade in the city: the "wicked, cruel and seditious" behavior of Alexandria's governors, he said, had reached "unheard-of excess." They demanded payments from French ships, refused to allow cargoes to be unloaded, and generally obstructed the flow of commerce. Roboly was more necessary than ever. Using his friendships with high-ranking officials, and especially with Alexandria's Jewish customs agents, Roboly was able to help set French commerce back on an even keel by I $764 \cdot{ }^{21}$

It did not hurt that Roboly had a vested interest in facilitating trade. Dragomans were not, on the whole, well rewarded for their work. In supplement to their small salaries, it was customary for them to receive a portion of ancrages, a tax paid by incoming ships. It was also common, albeit officially prohibited, for them to engage in private trade-which Roboly certainly did. A one-off venture

18. Enfants de langue et Drogmans, 53-60.

I9. "Mémoire envoyé par M. le Cte. De St. Priest," 6.

20. Roboly to ministry, March 24, I766, AN: AE B/ I/ı09.

21. See Fort's letters from these years in AN: AE B/I/Io9. The commercial resurgence that he observed was due more generally to the ending of the Seven Years War. For a slightly later Ottoman critique of extortionate behavior among the Egyptian beys, commissioned for the Porte in I 785 from the governor of Syria, Cezzâr Ahmed Pasha, see Ottoman Egypt in the Eighteenth Century: The Nizâmnâme-i Misir of Cezzâr Abmed Pasha, ed. and trans. Stanford J. Shaw (Cambridge, MA: Harvard University Press, i962). 
of his (and there must have been more) involved shipping tobacco from Salonika to Genoa, in conjunction with a local French merchant and with Jewish traders in Greece. But his chief business seems to have been exporting rice and coffee, staples of Egyptian trade, to Salonika and Smyrna. It was a veritable multinational concern, which took advantage of all his cosmopolitan connections: kinsmen could probably help Roboly in Smyrna and Salonika, while his partners in Alexandria were Muslim merchants hailing from Crete, Persia, and Greece. ${ }^{22}$

Another, more unusual, endeavor was Roboly's collecting of antiquities. Though the catacombs of Kom ash-Shuqaffa were only discovered in 1900-by accident, when a donkey slipped through a hole in the ground-Alexandria's denizens had long known about the buried ancient tunnels beneath the city. Roboly certainly did, and he also knew about the high social value his European contemporaries placed on antiquities. He intended to make the most of it. In a I75I letter to Versailles, the French consul reported:

I have read to Sieur Roboly the response with which you honored me, Monseigneur, on the subject of his statues and antiques. Since $M$. de Tournehem does not deem it appropriate to acquire them for the King ... this dragoman ... will profit from the first occasion that presents itself to dispose of them advantageously. I have nothing to add to the wise and judicious observations of M. de Boze; he is able to judge the merit of these sorts of monuments more surely . . . than I. ${ }^{23}$

It is a brief passage, but a very tantalizing one, not least because it presents an early documented example of European antiquities-collecting in Egypt. It also suggests Roboly's considerable powers of self-promotion. ${ }^{24}$ Here was an obscure functionary in a second-tier French consulate who had managed to attract the attention of the Parisian elite (Le Normand de Tournehem was Mme. de Pompadour's guardian, and Monsieur de Boze a noted book collector and connoisseur) and even to make propositions to the king himself. This was no small achievement.

In $176_{3}$, Roboly's interest in antiquities-collecting was enhanced when he made a fascinating, influential new friend: Edward Wortley Montagu (or as one French diplomat rendered the name, "Edoüard d'Owertlay Chevalier de Mon22. Fort to ministry, September i I, I767, AN: AE B/
I/ıo9; January 26, I768, AN: AE B/I/I Io.

23. Sulause to ministry, December 8, I75 I, AN: AE B/ $\mathrm{I} / \mathrm{IO} 7$.

24. But see the equally tantalizing unfootnoted quotation from Sulause in Leslie Greener, The Discovery of Egypt (New York: Dorset, I966), 77: "The great stir this discovery has made in the country, in spite of all the precautions taken to keep it secret, prove beyond anything one could say, how much these three statues verily smell of antiquity. The authorities, indifferent to this kind of thing, of which they take no notice ordinarily, have become so annoyed at not possessing them themselves, that they wanted to take them by command from sieur Roboly ... and it is only by the use of tact, manouevre, and money that he managed to calm their envy." 
taigu"), the irresistibly eccentric son of the celebrated Eastern traveler Lady Mary Wortley Montagu. ${ }^{25}$ The French consul in Rashid, where Montagu settled, could not believe his eyes when he encountered this bizarre Englishman. Not only had Montagu come to Egypt simply "for curiosity" - already unusual enough, at a time when few Western Europeans ventured even as far as Greece. Within weeks, he had "abandoned the rank of a person of his station, and became friends with all manner of Turks . . . adopting all their ways be they hard or soft, of eating, drinking, dressing, etc. ... He knows Arabic well enough to be understood and he is studying to make it perfect." Montagu was also "a great friend of the French, enchanting them (leur fascinant les yeux) with his manners." And Etienne Roboly had ample opportunity to fall under his spell: Montagu made a threeweek trip around the delta "to see and find antiquities there," and Roboly went with him. ${ }^{26}$ The ambitious dragoman could only have been inspired by this charismatic collector, living proof that antiquarianism was a sport of gentlemen (even strange ones). Statues were in his reach. Consul Fort was in his debt and easy to manipulate. The time was ripe to approach the king of France again.

On the first day of spring in $1_{7} 65$, an eerie season, when the city bolted its doors tight against the plague, Fort wrote off to Versailles. "Sieur Roboly," he said, has acquired "a statue of white marble, which was found in the ruins of ancient Alexandria by the Catacombs. This piece . . . is provoking here, Monseigneur, the admiration of everybody, and especially those who have some knowledge of drawing and sculpture. It seems truly worthy of being . . placed in some Palace of the King or in one of His Majesty's gardens." He went on to make a diplomatic proposition: "Some people have expressed to M. Roboly the desire to buy this statue from him, but I do not think that this officer will let himself be seduced by self-interested motives to [sell it to] . . f foreigners . . . without first knowing what your Grandeur's thoughts about the object might be."27

This "magnificent fragment of antiquity" was virtually undamaged and stood some seven feet high. The following month, Fort sent along an accomplished pencil sketch of it by the Austrian consul, Agostini, "who possesses the art of painting and drawing." 28 The drawing answers one question straight away: Roboly's statue was nothing like the sculpture from pharaonic Egypt most familiar to museumgoers today-sleek, crowned rulers, squatting scribes,

25. Though the eldest son of a hugely rich family, Montagu had been left with what he felt to be the unfairly small sum of $£_{2,000}$ per annum on the deaths of his parents in ${ }_{17} 6 \mathrm{I}$ and 1762 . He spent ${ }_{17} 62-64$ in the Near East, and parts of $1769-75$ in Egypt, where he owned a house "thirty feet" from the French okel in Rosetta (Chaillan to ministry, August 8, I772, AN: AE B/I/970). The original Dictionary of National Biography concluded that "there is little doubt that he was more or less insane" (Leslie Ste- phen and Sidney Lee, eds., Dictionary of National Biography, 66 vols. [London: Smith, Elder, I885-I90I], I3:686).

26. Vaugrigneuse to ministry, October $26, \mathrm{I}_{7} 6_{3}, \mathrm{AN}$ : AE B/I/970.

27. Fort to ministry, March 22, I765, AN: AE B/I/IO9.

28. Fort to ministry, April 22, ${ }_{7} 65, \mathrm{AN}$ : AE B/I/Io9. 
and stiff-armed gods. This statue was a Roman Egyptian or Ptolemaic grande dame, enthroned on a winged chair, full-bosomed, high-browed, thin-lipped, and proud. She represented Egypt as metropolitan, Enlightenment Europe liked to see it (and primarily did see it until I798, when the French savants traveled to Upper Egypt and brought back detailed descriptions and drawings of the fantastic pharaonic monuments there). "All the connoisseurs," said Fort, including the visiting duc de Picquigny, a sprig of one of France's most distinguished families, thought her excellent. ${ }^{29}$ She conformed beautifully to prevailing European tastes, as exalted in Winckelmann's History of Ancient Art, published just the previous year.

Agostini's drawing was excellent, and it worked. Versailles expressed an interest in the piece by return of post. What did Roboly hope to gain from the transaction? Not money, for sure-at least not explicitly, since between gentlemen, that expectation would be crude. "It is enough that your Grandeur seems to want this piece of antiquity for him to sacrifice it," said Fort. No, Roboly looked for his rewards in the intangible currency of prestige. By "sacrificing" his statue for his king, he showed himself, in a single stroke, to be discerning, capable, generous, and loyal—all of which, naturally, he made sure the consul spelled out: "Sieur Roboly has had to spend a great deal here to procure the statue ... and it still costs him a lot of trouble, care and work. I doubt that anybody other than this Dragoman, who is as well-known in the area as he is esteemed, could have succeeded in getting this piece, and I dare say ... that this is one of the most upstanding people to be found in these parts." "Embellishing the King's antiquities Cabinet," continued Fort, was Roboly's only goal, "and he expressed to me several times his ardent desire to be able to have this honor." 30

In September I765, Roboly's wish was at last fulfilled. The statue was packed up, permission obtained from the authorities to export it (which was itself a tricky task, requiring all Roboly's manipulative skills), and it was loaded onto a Marseilles-bound ship. On the whole, the episode was a splendid piece of selfpromotion for Roboly — and a splendid example of how marginal figures could use collecting as a device to advance themselves in European society. ${ }^{31}$ The statue opened doors, just as Roboly had wished. Within six months, timing that was surely not accidental, he wrote directly to the minister to protest the suspension of anchorage fees-the only legal supplement to a dragoman's salary-and to

29. Fort to ministry, September $15,1765, \mathrm{AN}$ : AE B/ I/ıo9. Picquigny, later duc de Chaulnes, had fled for Egypt the day after his wedding in 1758 . The marriage was eventually dissolved; and the duke went on to write treatises on acids.

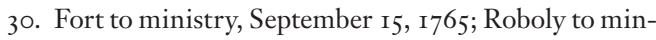
istry, September I5, I765, AN: AE B/I/ı09.
3. For parallel cases in contemporary India, see my "Collectors of Empire: Objects, Conquests, and Imperial Self-Fashioning," Past and Present, no. I84 (August 2004): I09-35. 
demand compensation. ${ }^{32}$ A direct address to the top brass by a low-ranking officer was most unusual, and only Roboly's recent coup with the statue could have emboldened him to make it. He also requested and received special permission to get married, a rare privilege for somebody of his rank. In March, I766, "without noise and ceremony," Roboly wed Maria de Sommo, daughter of a Neapolitan merchant based in Alexandria. ${ }^{33}$

It was no small irony that Roboly's patriotic gesture toward France hinged on his intimate local knowledge of Egypt — on his close contacts with Alexandria's scavengers and port authorities alike. According to a visiting Briton, "when any of the Bedouins (the people who spend their time in searching among the ruins) find any [antiquities], they generally offer them first to him." 34 Perhaps this was Roboly's greatest talent. For while his position as dragoman made him almost by definition a man of the margins, a permanent go-between, it also gave him the wherewithal to make his mark on a European elite and to assert his loyalty to France. Collecting paved a way from the cosmopolitan to the metropolitan, from Egypt to France.

And his arrest by the Turks, on July 20, I767, would show just why he had been so concerned to prove his "Frenchness" all along.

At one o'clock in the morning after Roboly's capture, the officer who seized him, Ali Capitan, Ottoman vice admiral, barged into the French compound, calling for the consul. He demanded a substantial bail for Roboly and spelled out the charges against the dragoman. Fort, bewildered and terrified, took up a quivering pen to convey the news: "All that I have been able to learn up till now is that enemies he has in Constantinople gave the Grand Vizier to understand that this dragoman is not French, but Armenian, a raya [subject] of the Grand Seigneur; that he never paid the Karach [tax] . . . [and] that . . . he loaded French boats with all kinds of products, and under the pretext of sending them to Smyrna, Salonika, and other countries under Ottoman rule, he sent them to Christendom." 35 This stunning set of allegations was all "an abominable lie if ever there was one," he insisted, and a gross violation of the "capitulations" - the agreements outlining European privileges in the Ottoman empire-that shielded French subjects from Ottoman law. ${ }^{36}$ But the more Fort pleaded for Roboly, the more they abused him. Egyptians who saw the dragoman down in the harbor reported that the Turks treated him worse than a slave. It would be a miracle if he reached Constantinople

32. Roboly to ministry, March 5, I766; March 24, I766, AN: AE B/I/Iog.

33. Fort to ministry, March ıо, I766, AN: AE B/I/ıo9.

34. James Haynes, Travels in Several Parts of Turkey, Egypt, and the Holy Land (London, I774), 40. 
alive. Fort was hysterical with fear. They might be coming for him next! "No Frenchman is safe in this country." ${ }^{7}$ And without a dragoman, he was of course paralyzed, unable to communicate.

Vergennes, the French ambassador in Constantinople, protested personally to the grand vizier about this outrageous abuse of diplomatic conventions. France's chief dragoman in Cairo went to the pasha of Egypt and actually showed him the article of the written capitulations that forbade the arrest of a French subject. Yet these efforts to free Roboly were to no avail. In Alexandria, French trade was in ruins; merchants, customs officials, and the consulate's Jewish dragoman fled in fear for their lives. And on the Reala, Roboly continued to "groan in chains," sometimes up to twenty-five hundredweight of them, lashed to the slaves down in the sordid bowels of the ship. ${ }^{38}$

What of the allegations against him? "Calumny," insisted Fort. But that Roboly was up to his ears in tricky business nobody could deny. Even Fort never confidently said that Roboly did not smuggle rice out of the Ottoman empire; he merely said that the accusations were unproven. And what about Roboly's Frenchness? This was the crux of the case: if Roboly really was Armenian, as the Turks alleged, then the rest of their charges were justified; he had indeed dodged his taxes for forty years and had entered French service without the sultan's permission. If, on the other hand, he was really French, then his arrest was an absolute and inexcusable violation of the capitulations-a casus belli, should France choose to make it so. (In I830 France would invade Algeria on a lesser pretext, in retaliation for an incident three years before, when the dey of Algiers struck the French consul with a fly whisk.) Fort and his superiors in Cairo and Constantinople referred again and again to the capitulations in their attempts to free Roboly, insisting that he was French. But one piece of evidence is conspicuously absent. Not once, in over twenty documents on the subject, does anybody say where Roboly was born. This single fact could have proved the point beyond doubt-if, that is, Roboly had been a native-born Frenchman.

Roboly must have known things could only get worse when the ship set sail, bound first for Syria, then on to the imperial capital. A tiny scrap of his writing, scrawled on a quarter-sheet of paper, slanted and nearly illegible, survives to tell of his torment. It took the ship an arduous thirty-three days from Syria, tossed on the swell of autumn storms, to reach land again. He arrived in Constantinople on December 22, five months and two days from the start of his captivity on the ship. But land was no better. He was immediately loaded down with chains and flung into prison with the slaves, the sultan's dreaded bagnio, from which even a slip of paper would be lucky to get out. ${ }^{39}$ Astonishingly, Roboly had survived the

37. Fort to ministry, July 25, I767, AN: AE B/I/Io9.

38. Fort to Vergennes, August 7, I4, 31, and September II, I767, AN: AE B/I/IO9.
39. Roboly to Fort, September 2, I767, AN: AE B/I/Io9; Fort to ministry, January 26, I768, AN: AE B/I/I Io. 
voyage, but the slave prison was too much. On April I5, I768, "broken by suffering and worry," Roboly died, with the slaves, a captive of the sultan. After nearly a year of sustained torture, for him and for his employers, it must have been a kind of release.

Roboly's arrest and captivity were part of the greatest crisis in FrenchEgyptian relations for a generation - an indirect consequence of what, in retrospect, was also one of the biggest political upheavals in Egypt until the French invasion in I798. And it was just this kind of explicit, traumatic, personal experience that helped formalize French imperial designs on Egypt. (The blueprint for Napoleon's invasion would be drafted by a prominent, long-term French expatriate in Egypt called Charles Magallon, who lost most of his fortune in I786, when the Ottomans deposed the leading beys in an attempt to reassert authority.) It took at least two years for things to settle down in Alexandria. And it took nearly ten years for the whole truth about Roboly to come out. It appeared in a report written by the comte de Saint Priest, French ambassador in Constantinople from 1769 to 1784 , which recommended wide-ranging reforms for Levantine consulates and for the dragoman service in particular. Speaking of the practice of choosing dragomans born in the Levant, Saint Priest said: "The Porte has never wanted to recognize French citizenship to children born in its states. . . Sr. Roboly, Dragoman of France in Alexandria, born in Constantinople, was recently the victim of this principle." 40 Born in Constantinople - perhaps of mixed parentage, perhaps never having visited France at all. The French called Roboly French, and the Ottomans called him Ottoman. The likely truth, which neither of these competing definitions could accommodate, was that Etienne Roboly was both: claimed by an imperial identity, while laying claim to a national one.

Though Roboly "had the reputation for being rich," when Consul Fort

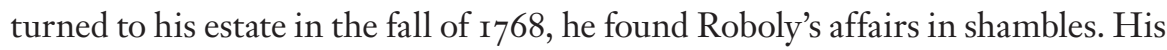
assets were "in the hands of Turks, Moors, and Greeks, dispersed around Egypt and the Levant, and for the most part now insolvent, or of bad faith"; his debts were greater. ${ }^{41}$ Ambassador Vergennes arranged a pension of five hundred livres for his widow, Maria. Roboly's story ends with one last unconventional letter to Versailles. It is written in one hand and signed in another, clearly unaccustomed to the pen: "La Veuve Roboly"— the Widow Roboly. "The King's goodness," she said,

will never be erased from my memory and [I] will ... number among my most essential duties the obligation to pray to God for the prolongation and happiness of His Majesty's days. The sentiment of humanity which has made Your Grandeur take an interest in my unfortunate plight, makes me look at the Grace that the King has been so kind as

40. "Mémoire envoyé par M. le Cte. De St. Priest," 6-7. ～4I. Fort to ministry, August 2 I, I768, AN: AE B/I/I IO. 
to offer me, as a good which I owe to the generous feelings of Your Grandeur, to whom I can only very feebly express the true recognition which I hold in my heart. ${ }^{42}$

Roboly would have approved of his wife's loyalty to the king of France. After all, he had died seeking acknowledgment of his own allegiance to France. In much the way that he had helped pull Frenchmen back from "turning Turk," he had been arrested for "turning French." He died, under Ottoman law, an Ottoman subject. But in death, with the belated interest of France in his affairs and the award of a state pension for his (Italian-born) wife, was he not also in some sense validated as French?

After more than a year of imagining Alexandria from the pages of crumbly archival volumes and literature, I finally visited the city in May, 200I. Since the eighteenth century, Western visitors to Alexandria, steeped in tales of Alexander and Cleopatra, have lamented the absence of visible ancient vestiges. Little remains standing of the ancient city but a single column, known as Pompey's Pillar, perched on a weedy ridge south of town. (Florence Nightingale, for instance, "went to the catacombs" in I849, "which, after those of Rome, are rather a farce; to Pompey's Pillar, through a great dismal cemetery: I thought we were coming to the end of the world." ${ }^{43}$ But today the city invites reflections on a different set of absences.

It seems more than coincidence that Roboly's collision with identity and empire took place in Alexandria, since his experience eerily foreshadowed the postcolonial history of Alexandria itself. Had he been born a century and a half later, Roboly would have found himself wrong-footed for a different set of reasons concerning national and imperial identities. The nineteenth and early twentieth centuries had seen Alexandria's population reach its high-water mark of diversity, with up to 30 percent of its inhabitants hailing from non-Arab or non-Muslim ethnic and religious communities. ${ }^{44}$ In 1956, President Gamel Abdel Nasser passed legislation nationalizing foreign-owned companies and encouraging (or in some cases forcing) foreign nationals and "non-Egyptians" to leave. Massive exoduses of Jews, Greeks, and other minority groups followed; and within a couple of years the city's population was, as it remains, composed almost entirely of people considered to be Egyptian. ${ }^{45}$ Etienne Roboly had painfully experienced the

42. Maria Roboly to ministry, November 21, I768, AN: $\mathrm{AE} \mathrm{B/I/I} \mathrm{Io.}$

43. Florence Nightingale, Letters from Egypt: A fourney on the Nile, I849-5o (New York: Grove, I987), 25.

44. It is hard to quantify these communities in part because of shaky definitions of "foreign" or "European" status. To give one example, however, according to an I 878 tally, there were almost 43,000 "Europeans" living in the city. The total population at that time was approximately 220,000. See Reimer, Colonial Bridgehead, i6o, I 10.

45. For a somewhat fictionalized, firsthand account of cosmopolitan Alexandria and its demographic transformation, see André Aciman, Out of Egypt: A Memoir (New York: Farrar, Straus, and Giroux, I994). 
potential dangers of an inclusionary, imperial definition of identity that claimed him as Ottoman within an imperial regime that included Armenians, like other minority groups (or dhimmis), among the taxable ranks of its subjects. But in the postcolonial era, as a non-Muslim, non-Arab, and non-"Egyptian," he would have been shunted out of Alexandria by a nationalist and fundamentally exclusionary definition of identity-one that completely transformed the city itself.

Only two generations ago, you would have been hard-pressed to find Arabic-speakers in certain parts of central Alexandria. Now it felt as if I was the only foreigner to spend more than a night there. Imagine London or New York without their ethnic communities: London's Edgware Road without the Lebanese eateries; Chinatown shop fronts without roasted ducks in the window; Twentyninth and Lexington without the smell of curry and spices. Imagine Spanish Harlem with the bodega signs faded out and only English on the streets; or Brick Lane without Bengali. That was a bit how Alexandria seemed now. "It's all changed," says an Alexandrian Greek in Naguib Mahfouz's novel Miramar. "My dear," ripostes her Egyptian friend, "it had to be claimed by its people." 46 The cosmopolitan cityscape remains, inhabited by a largely homogeneous "native" population.

I walked past art deco apartment blocks and peered into grand, decrepit foyers with rococo plasterwork and dust-caked elevator grills, marble stairs with dented brass railings. They were lit by bright, naked bulbs of irregular sizes, as if each had been hand-blown to order. My hotel also gave off the distinct sense of being a relic. In the lobby was a telephone the size of a cash register, with a crank on the side and cloth-wound wires, and a glass case filled with tatty stuffed birds, surmounted by a swan, frozen in takeoff or landing, it was unclear which. I sat in Western-style cafés, a novelty in a country where cafés are very much men's worlds, for smoking hookahs and playing dominos. Pastroudis, once the haunt of Alexandria's cosmopolitan elite, seemed like a set on an abandoned Hollywood lot. A whole wall of Sophianapolou's coffee store, with its big brass roasting machines, was covered with a poster of the Kaaba at Mecca by night. One afternoon, I was at a café on the Midan Saad Zaghloul, facing the sea, diligently plowing my way through Lawrence Durrell's Alexandria Quartet, when I heard another reminder of changed times: a throat clearing, a cough, and a tentative "allabu akbar." Somebody had set himself up with a loudspeaker in the square to conduct prayers. Men crossed the street to join him; minibuses pulled over and drivers jumped out. And for ten minutes, in answer to this makeshift call amid the azans from area mosques, men prayed on plastic mats, twenty feet away from 
the Hotel Cecil—where Durrell had staged scenes in his rather chauvinistically non-Muslim, non-Arab tales of Alexandria past.

But the most vivid sense of what had vanished came when I wandered around the antique market in the Attarin district of town. Only a couple of stores had distinctively Middle Eastern items (octagonal tables, inlaid mirrors, antique brassware). Shop after shop was filled, instead, with European-style furnishings, heavy rosewood armchairs and bulbous little chests, garish crystal chandeliers. There were oil paintings of autumnal Western landscapes, Arab horsemen against lurid orange hills and skies, and women of indeterminate ethnicity, captured in states between posing, pouting, lounging, and contemplating. There were assorted metal cups, trophies, browned family photos in frames, cigarette cases, and trinkets so corroded it was impossible to tell what metal they were made of. Only gradually did it strike me what all this stuff was: the debris of the families who left Alexandria behind, after 1956. These were the true relics of the city's cosmopolitan past, now being bought up and absorbed into Egyptian homes, or bought for export and sent "back" to the West. Like Etienne Roboly, or like the families who had once owned them, these objects, at home in a cosmopolitan setting, now had to take sides.

Of course, one only needs to read Durrell, with his ethnocentric, neoOrientalist perspective on Egypt, to see why the city needed to be reclaimed, as Mahfouz put it, by its people-just as one only needs to survey Egypt's modern history, in thrall to Western informal and later formal empire, to understand why Nasser nationalized the Suez Canal. And the prayers by the Hotel Cecil, or the antique objects changing hands, show that some forms of cultural juxtaposition, even mixing, remain part of the present-day Alexandrian scene. But one lesson from all this is obvious: nation-states, as the briefest glance at twentieth-century history will confirm, have often proved themselves to be hostile toward minority populations. Everybody knows that nationalism is not nice. Yet we have also been taught to see empires as evil things, which makes the second lesson-that empires have sometimes been more accommodating of difference than many independent nations - seem somewhat counterintuitive. Rather than looking at empire only as a force of division and control, segregating cultures according to racial or ethnic hierarchies, the history of Alexandria invites us to look at how empire may provide an umbrella of common security for people from a range of cultures to coexist, and at times even intermingle. ${ }^{47}$ This is not to say, of course, that empires treat all people fairly, without prejudice. Nor is it to overlook the ways in which, for many postcolonial nation-states, imperial legacies have cursed 
the process of identity-formation from the outset. If anything, Roboly's story shows that neither nations nor empires can claim to possess the secret to harmonious cosmopolitanism per se. The larger question is whether and how inclusionary definitions of belonging can be made to outweigh exclusionary ones-and whether empires or nation-states can find ways of embracing human difference in tolerant, even congenial, forms. 